\title{
The National Plans to Curb Unemployment and Inflation
}

\author{
by ROGER W. SPENCER
}

I OW RATES of inflation and unemployment have not occurred simultaneously in this country for a number of years. Each successive administration has been committed to take actions to achieve this objective since the Employment Act of 1946. The current Administration's programs to lower the inflation and unemployment rates have run the gamut from basically laissez faire policies to the unprecedented use of peacetime price and wage controls. Achievement of the two goals has been hampered by inherited price pressures on the one hand and adverse labor market developments on the other.

The tools available to any administration for the attainment of these two economic goals include aggregate budget (demand management) actions, and structural price and employment measures. In addition, fiscal authorities indirectly influence monetary actions through changes in the budget deficit or surplus.

The case for vigorous manipulation of these policy tools should not be overstated. Most analysts recognize the potential of price and wage controls, for example, to harm, rather than benefit, economic society. Also, the single-minded pursuit of, say, lower unemployment rates through stimulative demand management policies will result in some temporary gains in employment, but, in addition, may generate advancing price pressures. In the past, such stimulative policies have been typically reversed to curb inflation, with an important side effect having been a rise in unemployment. This particular scenario of events occurred most recently in the period from the mid-1960s to the early 1970 s.

This article reviews the national plans to curb unemployment and inflation, as such plans are identified in annual budget and economic report documents. Programs found in the most recent annual reports are stressed, but earlier policies are also discussed in order to gain perspective in surveying the current Administration's plans. Plans - and actions - suggest that imaginative structural price programs have been employed in recent years in an attempt to hold inflam tionary pressures in check, while stimulative fiscal and monetary actions have been taken to lower unemployment. The danger is that because of their apparent "success" when unemployment has been high, vig- orous inflation controls may be inappropriately called for during a period of excess demand.

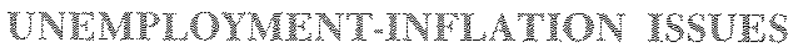

Presumably, the actions taken to attack unemployment and price problems are buttressed by plausible theories. Before reviewing such actions, it is useful to consider brielly some standard views of the sources of unemployment and inflation.

\section{Unemplonment}

Once an individual becomes unemployed, the underlying cause of his inability to find an acceptable job at once is the cost of obtaining information on all alternative employment possibilities. There are three basic sources of the initial period of measured unem. ployment: unemployment which arises from everyday frictions in the labor market, unemployment due to structural factors, and unemployment which arises from unanticipated declines in the growth rate of aggregate demand. ${ }^{1}$

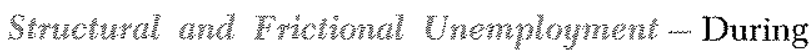
any given period there will be substantial changes in the demand for and supply of workers in particular industries. These structural demand and supply shifts lead to short-run changes in employment. Individuals adjust by changing their wage demands or by moving to other employment opportunities. For example, a sizable cutback in defense spending, accompanied by an increase in educational outlays, could lead workers in the aircraft industry to accept wage cuts, or leam a new skill, perhaps in the educational field. The transition period into the new field is often accompanied by temporary unemployment.

Similarly, short-run changes in employment levels occur with such normal frictional activity as workers leaving jobs to seek better opportunities, occasional business failures, work stoppages, and the irregular entry of new workers into the labor force. The unemployment which arises because of structural and frictional factors would, for the most part, occur regardless of the posture of monetary and aggregate fiscal stabilization actions.

\footnotetext{
iSee Roger W Spencer, "High Employment Without Inllation: On the Attainment of Admirable Goals," this Review (Sep" tember 1971), pp. 12-26.
} 
Aggregane Demand, Petaled Dnemployment Monetary and aggregate fiscal actions affect aggregate demand and thus influence the extent of unemployment arising from unanticipated changes in aggregate demand growth. Stimulative policy actions are followed by an increase in the demand for output and labor services. This increased demand is reflected in wages increasing at a more rapid rate than anticipated, on average, and a temporary lowering of the unemployinent rate.

When policy actions become restrictive, the demand for output and labor falls. Employers curb the growth of employment, while the supply of labor continues to increase. The result is a temporary rise in the unemployment rate.

Unusually large and continuous cutbacks in aggregate demand are capable of increasing unemployment sharply and for extended periods of time, as in the 1930s. Exceptionally stimulative aggregate demand actions can drive unemployment very low for considerable periods of time, as in the late 1960s. High unemployment rates were accompanied by price declines for much of the 1930s, and low unemployment rates were associated with price accelerations in the late 1960s.

"Normal" Unemployment-As mentioned earlier, the underlying cause of an unemployed workers' inability to immediately find and take an acceptable job is the absence of costless job information and mobility. An unemployed individual could obtain employment if he were aware of all feasible alternative job opportunities and wage rates, and had the resources to act on such opportunities. So long as he had a skill commanding some positive wage rate, and was not barred by law or custom from offering his labor servm ices, he would be able to obtain employment. However, high costs of obtaining job information and relocation do exist. Moreover, there is widespread non-price job discrimination.

Artificial curbs on the supply of labor tend to aggravate unemployment. For example, if a firm or labor group decides to permit only left-handed individuals to join their work force, job search time and costs to right-handed workers will be higher than otherwise. Many employment fields ranging from medicine to real estate either require licensing or restrict the number of entrants in some manner. A similar ability to control the number of apprentices is retained by many labor unions. Other institutional factors influencing job search time include minimum wage legislation, which adversely affects the employment opportunities of teenagers and other inexperienced workers, and the prevailing state of the communication and transportation networks.

When all these job market "imperfections," are taken into consideration, there is some "natural" or "normal" rate of unemployment which is largely independent of prevailing aggregate demand conditions. ${ }^{2}$ This level of unemployment consists of the unemployment engendered by structural and frictional forces. Aggregate demand is such that prices and wages are changing as anticipated, on average, and neither workers nor firms are misled by excessively stimulative or restrictive policy actions.

Structural measures to mitigate the adverse employment effects of licensing, union monopoly, and minimum wage restrictions could be appropriately used to lower the normal rate of unemployment. Manpower programs and job banks, which rapidly disseminate employment information, may also be of use in reducing structural and frictional unemployment. However, only stabilization policy actions have the capacity to both create and eliminate aggregate demand-related unemployment.

\section{Infation}

The underlying cause of inflation typically is excessive aggregate demand relative to the capacity for producing goods and services. Historically, inflation has occurred not only during the period of excessive aggregate demand, but for some time afterwards as well. This pattern of inflation was observed over the 1965-72 period. Excessively stimulative monetary and fiscal actions from 1965 to 1969 resulted in accelerating inflation. When stabilization policy actions became restrictive in the late $1960 \mathrm{~s}$ in order to curb the rapidly advancing prices, an early reaction of business firms was to slow employment and output growth, and only later to curb price increases. The initial phase of an inflationary build-up, in this case the period from 1965 to about 1969 , is often called "demand-pull", and the latter period, from 1970 to 1972 , is called the "cost-push" phase.

\footnotetext{
"See Milton Friedman, "The Role of Monetary Policy," the American Economic Review (March 1968), p. 9. "To avoid mistmderstanding, let me emphasize that by using the term 'natural' rate of unenployment, $I$ do not mean to suggest that it is immutable and unchangeable. On the contrary, many of the market characteristics that detemine its level are man-made and policy-made. In the United States, for example, legal minimum wage rates, the Walsh-Healy and Davis-Bacon Acts, and the strength of labor unions all make the natural rate of unemployment higher than it would otherwise be."
} 
The demand-pull concept of inflation is often associated with excessive aggregate demand policies and the cost-push concept is frequently associated with "monopolistic" wage and price-setting powers of labor unions and business firms. However, the view of costpush inflation described above holds that this phenomenon exists as a lagged consequence of earlier excessive aggregate demand.

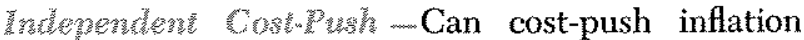
occur except as a consequence of earlier stimulative monetary and fiscal policy actions? It is possible that the price level could be forced up by restrictive practices of business and labor monopoly power independent of stabilization policy actions. However, without sustained rapid increases in the money stock, an enduring general inflation is not likely to occur. If the prices of some products were boosted in the absence of an increase in aggregate demand, price rises would likely result for only a short period as consumers adjusted their budgets toward the purchase of other competing goods. ${ }^{3}$

Supply reductions also affect the inflation rate. A reduction in the supply of an important commodity for which there are few, if any, good substitutes would have a greater effect on price increases than for a commodity with many good stubstitutes. ${ }^{*}$ Efforts to increase the supply of a critical commodity by lowering import barriers, or stimulating greater domestic output, could speed the period of adjustment.

If, somehow, the prices of all currently-produced goods could be increased in the absence of a rise in aggregate demand, the "inflation" would last only as long as it took wealth holders to discover that the real

SSimilarly, control programs may hold down prices of some directly controlled products, but prices of uncontrolled items, such as agricultural commodities in the Phase II 1972 experience, may rise. This point was cogently made in a recent Wall Street Joumal column. “. . . dollars created are likely to be spent somewhere. If consumers have $\$ 10$ and sellers offer five widgets and five gidgets, the widgets and gidgets can go for $\$ 1$ each. If suddenly consumers have $\$ 12$ and the stores still have the same five widgets and five gidgets, the price is likely to go up to $\$ 1.20$.

"So along comes some Hammurabi and says he will stone to death anyone who buys or sells a widget for more than $\$ 1$. So consumers can only spend $\$ 5$ for the five widgets. But this leaves them with $\$ 7$ to spend on the flve gidgets. Hammurabi is shocked to find that the price of gidgets soars to the unheard-of-height of $\$ 1.40$." See "How to Control Inflation," Wall Street Joumal, Jan. 10, 1973, p. 14.

AArmen A Alchian and William R. Allen University Economics 3rd ed. (Belmont, California: Wadsworth Publishing Company, Ine, 1972), p. 683, give an example of how a change in the physical stock of goods can generate price increases. "In a predoninantly agricultural society, if the annual harvest is unusually small, prices of goods will be higher than usual. A historically significant case occurred during The Black Death in England in the fourteenth century." value of their cash balances had declined, and that their spending rate should be reduced commensurately. In this case, the income velocity - or rate of turnover - of the money stock would have increased during the realization period, but would later return to its trend rate. A one-time only rise in the level of prices - but no continuing increase-would occur. Only increases in aggregate demand, whose variance around a trend is significantly influenced by monetary changes, could permit the inflation to continue for an extended period of time (assuming output is unaffected by these changes in nominal magnitudes).

Buste ponats - Two basic points of this analysis are that (1) significant, lasting progress against inflation can be achieved only by avoiding excessive demand pressures, and (2) gains in the inflation battle can possibly be obtained by structural attacks on businesslabor monopoly infuence through programs which increase the supply of goods and services. Any program based solely on direct price-wage restraints which ignores the effects of rising aggregate demand, may achieve some initial success in treating the symptoms of inflation. Over time, however, evidence from this country and others suggests that moderate stabilization actions alone can effectively combat inflation. ${ }^{5}$

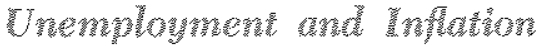

Unemployment and inflation are both affected by aggregate demand policy actions and structural changes. These influences are captured by a curve relating unemployment and prices, often called the Phillips curve. The Phillips curve is typically thought to reveal that high rates of unemployment are associated with low rates of price changes and low rates of unemployment are associated with rapid rates of

\footnotetext{
The 1970 Report of the Cauncil of Economic Advisers (CEA Report) notes that "Experience with such policies [direct price-wage measures] in other countries has been remarkably consistent. In some cases success in holding down wage settlements or price increases has been achieved in particular industries. There is usually a period in which these programs may have some overall deterrent effect, though evidence here is less certain. After an interval, however, there is a point at which accumulating pressures make the programs ineffective."

"American experience corformed to this pattern" (pp. 23-24).

The same conclusion was reached by two analysts who conducted an extensive survey of the European experience. They found that "... periods of apparent effectiveness were typically short-lived; they were frequently followed by wage or price explosions which sometimes blew up the policies themselves. Thus the policy at best seems to have been gaited for a short sprint rather than a long race, which suggests that it was better suited to deal with short-run emergencies like transient balance-of-payments disequilibria than with persistent inflationary forces." Lloyd Ulman and Robert J. Flanagan, Wage Restraints: A Study of lncome Policies in Westem Europe (Berkeley: University of California Press, 1971), p. 223.
} 
price advance. As the experience of the 1970-72 period indicates, there are times when high rates of unemployment co-exist with high rates of change of prices.

Periods representing all three of these price-unemployment combinations are found in Chart I. Instead of the usual "rounded $L$ " relationship the Phillips curve is presumed to reflect, the picture which emerges from a twenty-year plotting of price changes and unemployment rates in the United States looks more like a series of triangles, possibly depicting three stages in the business cycle. The triangles may be divided very roughly into periods of early recovery, full recovery, and recession.

In the early recovery period, the rate of increase of prices tends to drop sharply and the unemployment rate falls. ${ }^{6}$ Stimulative policy actions foster increased aggregate demand and declines in unemployment. Continued gains in aggregate demand result in demand-pull inflationary pressures as the economy moves into the full recovery zone. Movement into the full recovery zone is characterized, in general, by minor gains in lowering the unemployment rate and a marked pick-up in the inflation rate.

Stimulative stabilization policies are reversed to curb the rapidly advancing prices and a recession ensues. The recession is marked by a sharp rise in unemployment and some progress in reducing inflationary pressures. As indicated by Chart I, the duration of each stage is highly variable.

Is the Phillips relation, or business cycle triangle, inevitable? There is a view, which has received conm siderable theoretical support, which answers "No." The "no Phillips curve" theory argues that if aggregate demand policies were followed over a long period that permitted prices and wages to change at some steady, fully anticipated rate, unemployment would eventually settle at its normal (or natural) rate and not be associated with any particular rate of change of prices. If inflation is "fully and instantaneously discounted, the Phillips curve becomes a vertical line over the point of "equilibrium unemployment." "7 Effective structural unemployment and price policies could be used to shift the Phillips curve - whether in the form of a rounded $\mathrm{L}$, a triangle, or a verticle line

\footnotetext{
6A more complete Phillips curve scenario is given in Roger Spencer, "The Relation Between Prices and Enployment: Two Views," this Review (March 1969), pp. 15-21.

"Henry C. Wallich, "The American Council of Economic Advisers and the German Sachverstaendigentat: A Study in the Economics of Advice," The Quarterly Joumal of Economics (August 1968), p. 356.
}

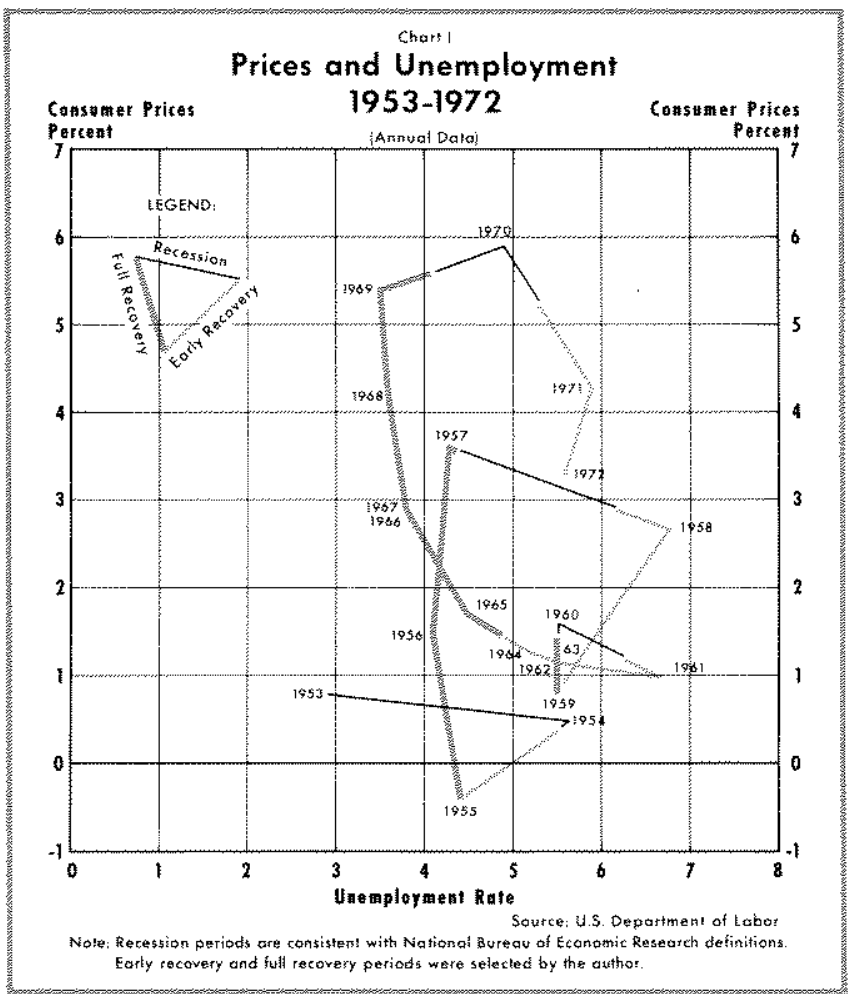

- regardless of the propriety of aggregate demand policies.

Stop-and-go aggregate demand policies have probably hampered the attainment of the no trade-off state envisioned by proponents of the long-run vertical line view. In addition, these policies have affected the timing involved in the price-unemployment movements around the triangle. The intensity of a particular aggregate demand policy action and the length of the period over which it is applied influence the ob. served reaction lag of unemployment and prices. Thus the recession, early recovery, and full recovery stages should not be expected to begin at the same unemployment-price combinations.

Also of considerable importance to unemploymentprice movements is the level of the normal rate of unemployment. The nornal rate is variable and moves with changes in the structure of the labor market. If stimulative aggregate demand policy actions were undertaken with an existing 5 percent unemployment rate when the normal unemployment rate was 5 percent, more inflation would result than if the normal rate were 4 percent (given other comparable initial conditions). Thus, to achieve unemployment and price goals, policymakers should recognize both the lags associated with aggregate demand policies and the state of the labor market, particularly when the economy is moving toward the full recovery stage. 
At the current time (early 1973) it appears from Chart I that the re-entry into the full recovery stage (as suggested by the unemployment-price projections of most private forecasters) of the present business cycle will occur at a rate of price increase far exceeding that of earlier comparable periods. The highest previous rate of price increase at the full recovery threshold was between 1 and 2 percent in the mid1960s. Excessively stimulative aggregate demand policies at this stage would propel the economy toward the next phase in the cycle at rates of price increase yet above those of the late $1960 \mathrm{~s}$.

\section{A Summing Uy}

This brief description of some of the prevailing views of price-unemployment issues provides a background for surveying the national economic plans. In light of the above, three considerations emerge in the formulation of a national plan to deal with unemployment and inflation.

First, there is the appropriate use of aggregate demand policies which affect both unemployment and inflation. The national plans should demonstrate an awareness at this time of the "re-entry" problems encountered as the economy moves from the early recovery to the full recovery stage of the business cycle. Since stop-and-go aggregate demand policies are often recognized as having necessitated the re-entry itself, consideration also should be given to the long-run effect of current policies.

Second, structural employment programs should attempt to reduce the costs of information associated with job search. Such programs might provide information directly or do so indirectly by lowering artificial employment barriers. Outlays for direct employment assistance, such as manpower training programs and job banks, are, of course, subject to diminishing marginal returns.

Third, the inherent limitations of structural programs to curb inflation must also be recognized. Control programs may have some temporarily beneficial effect on prices, but no basic supply and demand factors are influenced. Policies designed to increase the supply of goods and services, such as the relaxation of import controls and crop acreage allotments, would likely provide more lasting benefit.

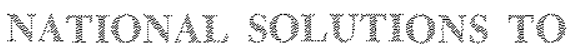

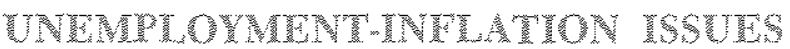

The national plans which are intended to result in early achievement of low rates of unemployment and inflation may be divided, for purposes of analysis, into aggregate demand policies and structural programs. These tools are examined as they relate, first to unemployment alone, next to inflation, and finally to both unemployment and inflation.

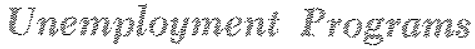

Changes in the size and composition of the labor force in recent years may have contributed to the relatively high unemployment rates of the early 1970 s. Even when aggregate demand policies stimulate total employment, little progress can be expected in lowering the unemployment rate if the civilian labor force also increases at a rapid pace. Moreover, the aggregate unemployment rate is adversely affected if the costs of job information are particularly high for large segments of the labor force seeking employment.

In the first year and a half following the 1969-70 recession, civilian employment increased at a 2.5 percent annual rate, but the civilian labor force rose at a 2.3 percent rate (compared to a 1950-70 trend rate of 1.4 percent). As a result, the unemployment rate remained at about the 6 percent level. The labor force increases were a consequence of large increases in the total population of labor force age, and of significant changes in labor force participation rates.

There is considerable evidence that the present Administration recognizes the impact of the changing structure of the labor market; however, attempts to alleviate structural and frictional unemployment through sweeping, innovative programs - such as those of the early and mid-1960s - have not been undertaken. (One reason for this may be the ineffciencies alleged in some of these earlier programs.)

Ample evidence of the awareness of the problem can be found in the CEA Reports. The 1970 Report discusses the progress and value of the Job Bank Program, which makes available computerized lists of available jobs with the objective of lowering the costs of information.

Ways should be sought to reduce this cost [of 'frictional' unemployment], without losing the attendant benefits. For example, information plays a crucial role in the process of satisfactorly matching workers with jobs. Providing job information may be a worthwhile social investment, decreasing the time and effort workers must typically spend in search of suitable employment and improving labor utilization. The Department of Labor has long played a leading role in gathering and disseminating job market in formation, and this Administration is accelerating the development and introduction of systems such as the Job Bank and experiments in computerized matching of workers with jobs.

\$1970 CEA Report, p. 149. 


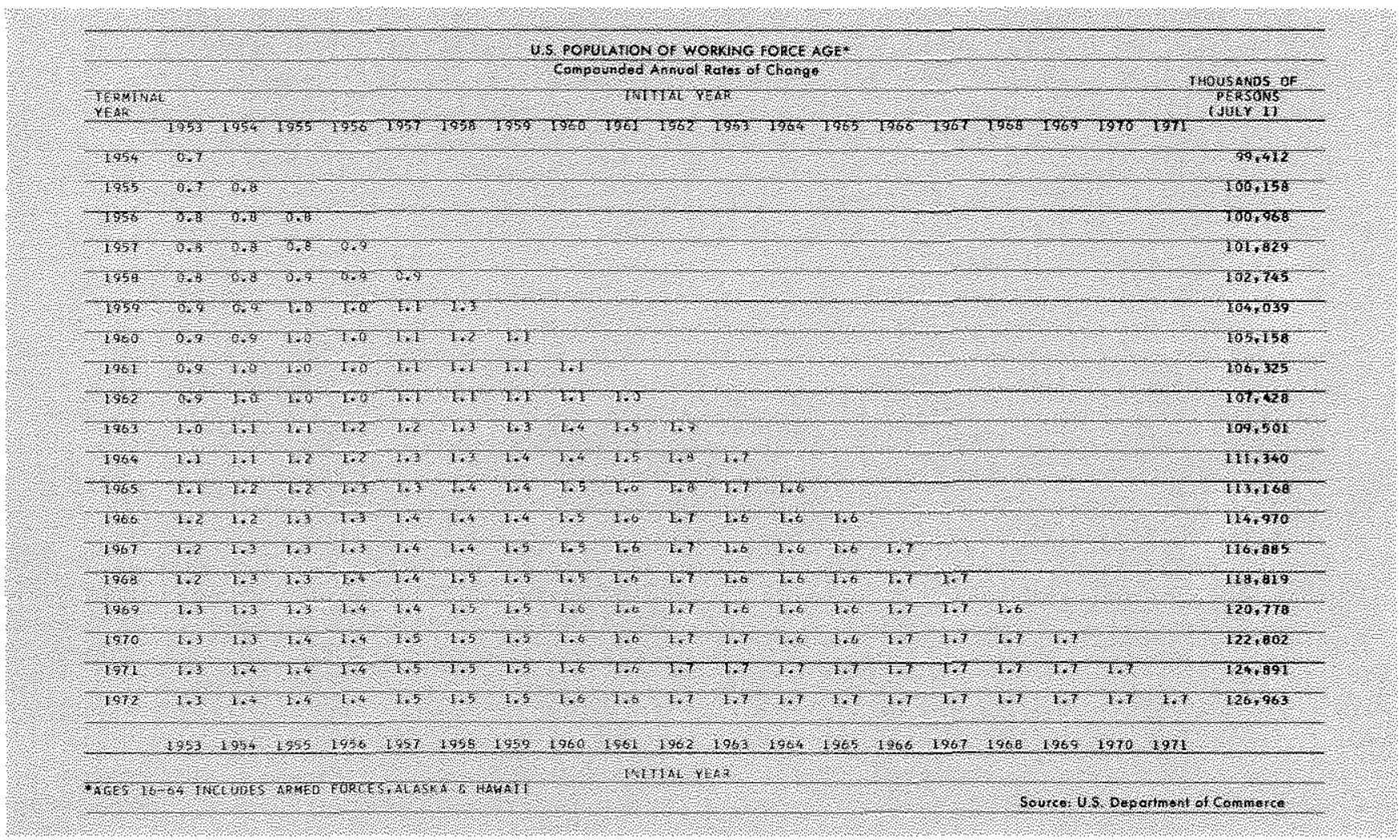

The 1970 CEA Report also makes reference to changes in the Job Corps and the Manpower Training programs designed to improve their efficiency of operation. ${ }^{9}$ Decentralized administration is emphasized, in particular. Neither the Job Bank, Job Corps, nor the Manpower Training concepts were originated by the current Administration.

The 1971 CEA Report briefly described the Administration's increase in budget outlays for manpower training programs. ${ }^{10}$ The 1972 CEA Report devoted considerable attention to the demographic-geographic structural unemployment problems. The structure of the labor force with regard to women, teenagers, Vietnam veterans, and the individual states is discussed. A brief digression on some of these structural problems is appropriate at this point.

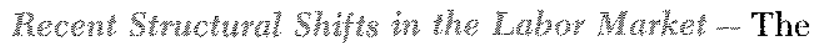
accompanying annual rate of change "triangle" gives rates of change in the population of labor force age (16-64 years). Largely because of an increasing birth rate in the 1946-57 period, the population of labor force age rose much more rapidly in the latest recession and early recovery years (1970-72) than in comparable recession-recovery periods of the $1950 \mathrm{~s}$ and

Trbid., pp. 63, 65.

301971 CEA Report, p. 90. early 1960 s. Chart II (p. 8), which traces the ratio of civilian employment to population of labor force age, indicates that this ratio was high in the 1970-72 period relative to the earlier recession-recovery periods. $\mathrm{Ci}$ vilian employment has increased at a rapid pace recently, relative to the earlier periods, considering the movements in population of labor force age.

Growth in the number of teenagers accounts for much of the increase in the population of labor force age in the 1962-72 period. Teenagers relative to the total population of labor force age increased from 4.6 percent in 1961 to 6.3 percent in 1972 . Moreover, their labor force participation rate rose from 47 percent to 52 percent over the same period. High costs of job information (owing to inexperience, institutional and legal constraints) and a lack of mobility keep teenage unemployment rates above those of other labor force age groups. For example, if a teenager were able to locate employment (either above or below the minimum wage) in another town, there would be many constraints on his ability to move there.

Another group whose participation rate has increased rapidly in recent years is females. The participation rate of women in the labor force rose from 38.1 percent in 1961 to 43.9 percent in 1972 . The labor force participation rate of men over the same 


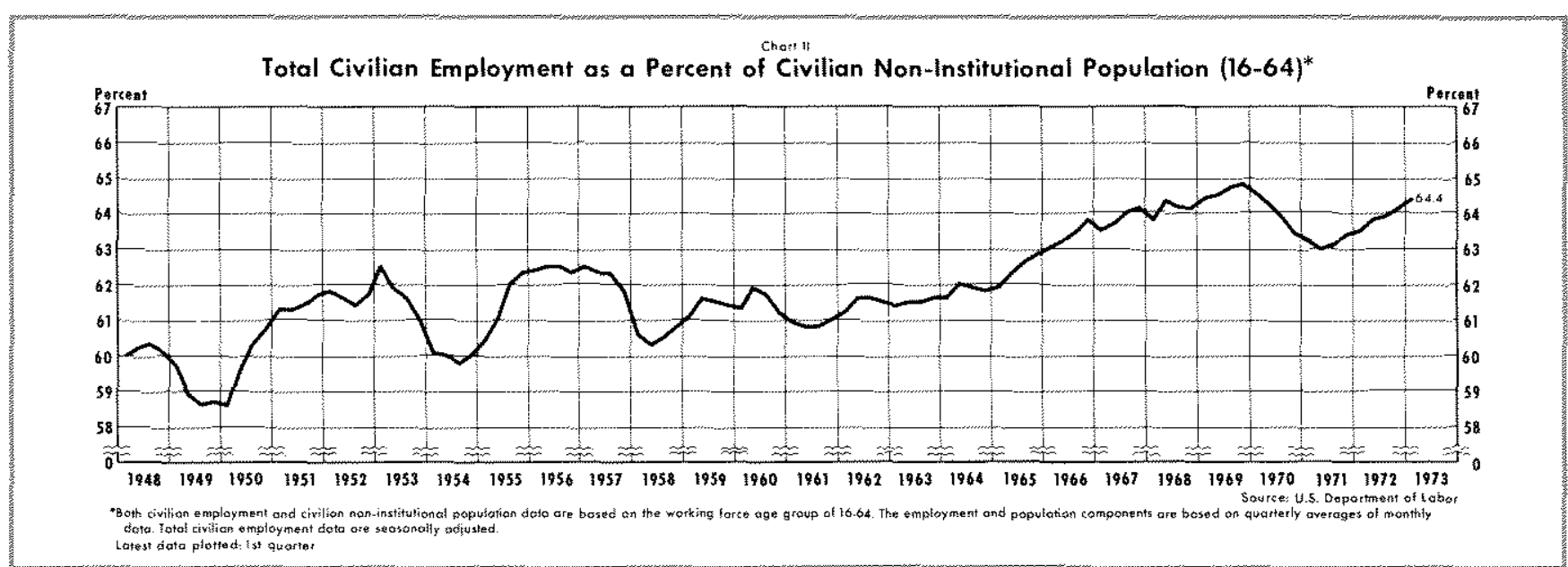

period fell from 82.9 percent to 79 percent. As a proportion of all unemployed individuals, women's umemployment rose from 36.4 percent to 45.6 percent.

Changes in the structure of the labor market over the past few years also occurred due to changing defense policies. With a declining manpower commitment to Vietnam since 1968 , the civilian labor force has had to absorb thousands of veterans, many with only defense-oriented job skills. At first, the veterans' unemployment rate remained well above that of their civilian counterparts, but recently the two rates have about coincided.

Cutbacks in defense expenditures also influenced significantly the geographic distribution of the unemployed. In 1971 the unemployment rate varied from 3.3 percent in Colorado to 11.1 percent in the state of Washington. Employment in Washington, California, and several other states was adversely affected by the reduction in outlays for defense and aerospace programs.

All these structural shifts in the demand for and supplies of labor may have resulted in a rise in the normal unemployment rate in the late 1960s and early 1970s. No conclusive evidence is available on movements of the normal unemployment rate, but if it has indeed increased in recent years, extensive use of structural unemployment measures would be appropriate to attain a low aggregate unemployment rate without incurring increased inflationary pressures.

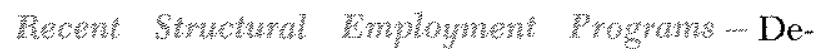
fense-related employment was cited in most CEA Reports, but in less detail than in the 1972 Report which described the formation of several new programs.

Project Transition, the Jobs for Veterans Committee, and, to a lesser extent, the Public Employment Pro- gram were designed to aid job-seeking veterans. ${ }^{11}$ The new Technology Mobilization and Reemployment program was created to mitigate structural unemployment among engineers, scientists and technicians fostered by defense cutbacks. ${ }^{12}$

An analysis of the age-sex employment problems presented in the 1972 CEA Report (p. 115) indicated that using 1956 age-sex rates, an unemployment rate of 4.1 percent in 1956 was equivalent to a 4.5 percent rate in 1971 . That is, changes in the composition of the labor force due primarily to more young people and more women in 1971 than 1956 resulted in an almost one-half percentage point increase in the unemploy ment rate, other things equal.

The Administration urged a lower minimum wage for teenagers as a partial solution to structural unemployment. Such a proposal was submitted to Congress in April 1973. As for women, their unemployment situation is described in detail in "The Economic Role of Women," a full chapter in the 1973 CEA Report. The Equal Employment Opportunity Act of 1972, liberalized child care tax deductions, and a requirement for certain Federal contractors to provide equal employment opportunities for women are among the solutions cited.

The Administration's 1973 employment programs which have received the most publicity are summarized in the 1974 budget message. Along with a proposal to consolidate a number of existing employment assistance programs through Special Revenue Sharing, the 1974 budget calls for an end to the Emergency Employment Assistance Program. Although outlays for some employment programs, such as "Work Incentives", are projected to rise in 1974 , the net effect of

\footnotetext{
11972 CEA Report, p. 109. The proposal of Manpower Revenue Sharing is also described (p, 111).

12Tbid., p. 110 .
} 


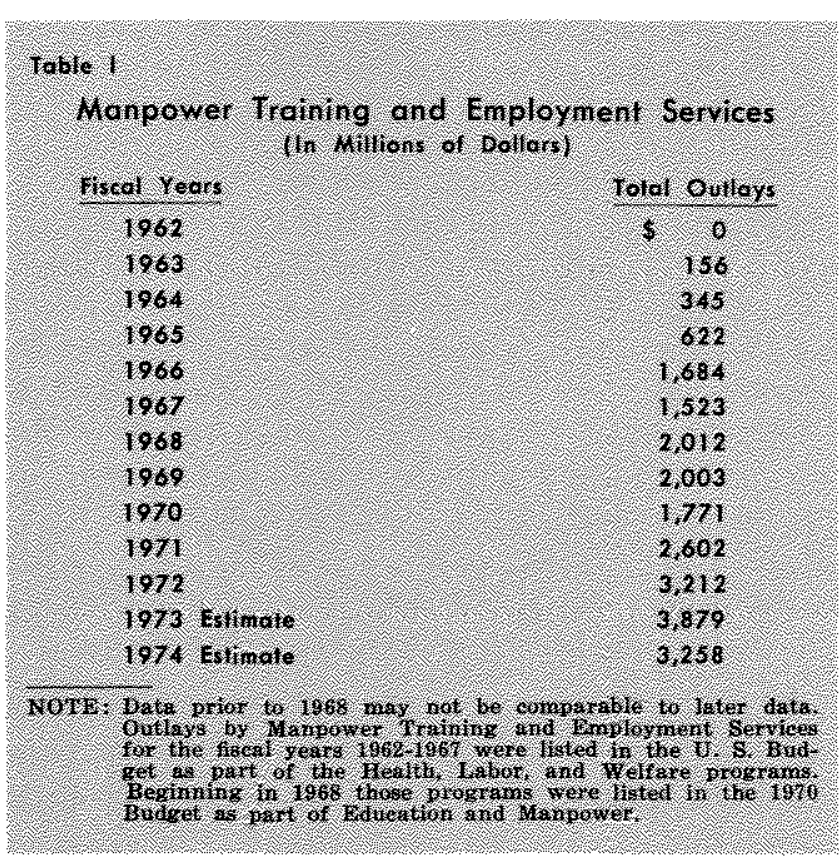

the elimination of Emergency Employment Assistance and other changes is a budgeted decline in employment expenditures from $\$ 3.9$ billion in 1973 to $\$ 3.3$ billion in 1974. This would be the largest year-to-year cutback in manpower programs since their inception in 1963 (see Table I).

The move towards consolidation and efficiency is more characteristic of the current Administration's efforts in the manpower area than is innovation. The major manpower legislation, in terms of dollar outlays or individuals affected, was enacted in the 1962-68 period. ${ }^{13}$ A seminal piece of legislation, the Manpower Development and Training Act of 1962, required the Administration to prepare a full report on manpower activities each year. Thus, manpower programs have been in existence long enough for some tentative evaluations to be made.

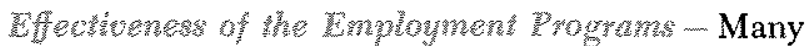
studies of the employment assistance programs have reported favorable results. However, these studies have usually not been marked by cost-benefit analysis.

At the elementary level of assessment, it is possible to obtain figures for the number of jobs filled by individual programs. For example, the $1972 \mathrm{CEA} R e-$ port indicated that direct efforts to find jobs for military veterans resulted in 320,000 job placements between June and October 1971; the Emergency

${ }^{13} \mathrm{~A}$ current listing and brief description of the major Federal work-training programs enacted in the $1962-71$ period is given in Sylvia S. Small, "Statistical Effect of Workn"Training Programs on the Unemployment Rate, "Monthly Labor Review (September 1972), pp. 8-9.
Employment Act of 1971 was responsible for providing over 75,000 jobs with state and local governments by the end of $1971^{14}$

In terms of the unemployment rate, one study found existing work-training programs in 1971 were responsible for the unemployment rate being 5.9 percent rather than 6.2 percent. ${ }^{15}$ A similar employment contribution was attributed to the work-training programs for the $1965-67$ period. ${ }^{16}$

These studies cannot say, of course, that the allocation of $\$ \mathrm{X}$ billion to lower the unemployment rate by $\mathrm{Y}$ percent resulted in a net increase in welfare. There is at least one study which attempts to determine, without going into welfare or utility analysis, the dollar increase in GNP ensuing from dollar outlays in manpower programs. C. C. Holt and his co-authors estimated that a $\$ 14$ billion expansion in such programs would result in a $\$ 30$ billion rise in gross national product.17 Moreover, they estimated that, with the same level of inflation that would correspond to a 4.5 percent unemployment rate in 1972 , the $\$ 14$ billion expansion of manpower programs would lower unemployment by 2.4 percentage points to the 2.1 percent level.

Robert E. Hall, in a far less optimistic article, put the reduction in unemployment due to the major expansion of manpower programs at only 0.4 percent that is, a fall from 4.5 percent to 4.1 percent. ${ }^{18}$ By making the simplistic assumption that changes in GNP are comparable to those in employment, Hall's estimate of a lowering of the unemployment rate by one-sixth of Holt et al. $\left(\frac{.4}{2.4}\right)$ would translate into a GNP gain of only $\$ 5$ billion vs. a $\$ 14$ billion cost.

141972 CEA Report, pp. 109-110.

${ }^{15}$ Sylvia Snall, "Work-Training Programs," p. 12.

16Malcolm S. Cohen, "The Direct Effects of Federal Manpower Programs in Reducing Unemployment" The Journal of Human Resources (Fall 1969), pp. 491-507. Cohen found that the programs led to a reduction in the unemployment rate of 0.4 percent in 1967 (from 4.2 to 3.8 ), 0.3 percent in 1966 , and 0.15 percent in 1965 .

17C. C. Holt, C. D. MacRae, S. O. Schweitzer, and R, E, Smith, "Manpower Proposals for Phase III," Brookings Papers on Economic Activity (3: 1971), p. 717 .

18Robert E. Hall, "Prospects for Shifting the Phillips Curve through Manpower Policy,"Brookings Papers on Economic Activity (3: 1971) p. 673. Hall and Holt et al., found the occupational mobility, vocational counseling and teenage work study, and employment service expansion programs to be of the most benefit in lowering the unemployment rate. As Hall points out, there is probably some double counting in the Holt et al. estimates in going from the micro to the macro implications of the programs. A more realistic estimate would probably be somewhere between the Hallm Holt et al findings. 
Despite these widely varying assessments, there is little doubt that, at some positive cost, the unemployment rate could be lowered through a major expansion of manpower programs. A potentially more efficient way to lower the unemployment rate through structural measures would be through the elimination of artificial barriers to employment, such as the minimum wage and non-price job discriminatory practices. Current research also suggests that government programs, such as unemployment compensation, which tend to reduce the incentive for job search are responsible for some unemployment. ${ }^{19}$

\section{Price Programs}

The initial efforts of the current Administration to curb inflationary pressures are recorded in the 1.970 CEA Report. Only aggregate demand tools were used, rather than direct price-wage measures because "the results of our own experience and numerous trials of such policies in other countries over the preceding 20 years did not justify confidence that such efforts would help the inflation problem in 1969." The sizable deficits and rapid monetary expansion of the several preceding years had led to a classic case of demand-pull inflation.

The 1971 CEA Report reflects some initial interest in structural price policies. Actions were taken to increase the supply of lumber and oil (the latter by easing restrictions on importation and production), in order to slow the advance of prices in these particular industries. Copper pricing policies were investigated and the Cabinet Committee on Economic Policy probed into economic conditions in the steel industry. Construction workers and employers were invited to submit plans which would lead to a slowing of wages and prices in the building sector.

Attempts were also made to improve the functioning of markets generally, as well as in the specific cases cited. The Council of Economic Advisers prepared periodic "Inflation Alerts" to "spotlight the significant areas of wage and price increases and objectively analyze their impact on the price level." "21 A

\footnotetext{
19See Martin S. Feldstein, "Policies to Lower the Permanent Rate of Unemployment," in United States Congress, Joint Economic Conmittee, Reducing Unemploument to 2 Per Cent, October 17, 1972, p. 27 . Feldstein argues that the disincentive effects of the unemployment compensation systen have increased the duration of unemployment in the United States. Moreover, "It is also noteworthy that when the British introduced earnings related unemployment benefits in 1966, their unemployment increased substantially and the previous relation between unemployment and vacancies broke down."

201970 CEA Report, p. 23.

21971 CEA Report, p. 63.
}

National Commission on Productivity was appointed to recommend measures which would increase productivity in various sectors of the economy.

The Federal Government's tendency to aggravate inflationary pressures in important areas was also recognized. The Regulations and Purchasing Review Board was established to review such problem areas as ". . . import restrictions, regulations which unduly increase the cost of bidding on small Government projects, design and procurement methods for Government buildings and the administration of the DavisBacon Act, which requires that contractors on Federal construction projects pay 'prevailing' wages (a provision which in practice may have exerted an inflationary effect on construction wage rates and costs ).

Taken as a whole, these were admirable programs to improve the functioning of the market system, some of which, if given time, could have contributed significantly to the slowing in the inflation rate which had begun by 1970. Given the duration and intensity of the inflation build-up prior to the moderately restrictive stabilization actions of 1969 , there was no reason to expect a sharp downturn in the rate of price advance in the early 1970 s. However, the progress in the inflation battle was not sufficient by August 1971 to satisfy the Administration, and sweeping price and wage controls were instituted at that time.

The controls program, announced August 15, 1971 , was established under the authority of the Economic Stabilization Act of 1970.23 As described in the 1972 CEA Report, the initial step in the program was "an immediate 90 -day freeze on prices, rents, wages, and salaries and creation of a Cabinet-level Cost of Living Council (CLC) to administer the freeze and to advise on further stabilization policies and actions." ${ }^{24}$

At the end of the 90-day freeze (or Phase I), a complex program of controls, supervised at the top level by the Cost of Living Council, was set in motion. The two principal elements of the new administrative machinery were the Price Commission, to which the Rent Advisory Board reported, and the Pay Board, to which the Executive Compensation Sub-Committee reported. Other new parts of the machinery were the Committee on Interest and Dividends, the Committee on Health Services Industry, the Committee on State and Local Government Cooperation, and the Agricul-

\footnotetext{
22Ibid., p. 81.

2:The same act was the basis for the construction industry program established in March 1971 and administered by the Construction Industry Stabilization Committee.

241972 CEA Report, p. 75 .
} 
ture Stabilization and Conservation Service. The National Commission on Productivity and the Construction Industry Stabilization Committee (CISC) were retained in the new framework. ${ }^{25}$

The Phase $I$ and II control programs were, according to the 1973 CEA Report, a success. "Judged by any expectations one could derive from history, either in the United States or abroad, the system was successful." The CEA does not attempt, however, to claim more for controls than is warranted by the data. They note that it is possible to observe that the rate of increase of prices was falling before the institution of controls, and the continued progress in the Phase I and II periods cannot be attributed wholly to their effects. ${ }^{27}$ For example, the quarterly fixed weight gross private product price index accelerated from a 4.1 percent rise for the year ending fourth quarter 1968 to a 5.1 percent increase in the following year. It then decelerated smoothly to 4.5 percent, 3.8 percent, and 3.3 percent in the years ending 1970,1971 , and 1972 , respectively. ${ }^{28}$

The admission of uncertainty about the extent of the effectiveness of controls on inflation is followed by the CEA's declaration of belief that the risk of price acceleration was substantially reduced. Even this mild claim ignores the possibility that controls may have only altered the observed inflation lag pattern, such that the acceleration of prices was simply postponed. The risk of a delayed acceleration was increased if prices were artificially restrained in the face of stimulative aggregate demand policy actions.

Despite the "successes" of Phase I and Phase II, much of the controls mechanism was altered in Phase III. Why? For very good reasons, as discussed in the 1973 CEA Report. The CEA notes that the costs of controls in terms of distortions and interferences with production and distribution, as well as administrative costs, were not great in the 1971-72 period, but they were growing.

They [the costs of controls] could be much more significant in 1973 as the program aged and as the economy came closer to its potential. The number of instances of excess demand would multiply, and the

25Considerably more detail is available on the Phase I and Phase II programs in the 1972 and 1973 CEA Reports.

201973 CEA Report, p. 51.

$2 \pi$ Ibid., pp. 60-62.

28The CEA also notes that although several econometric studies indicate controls lowered the rate of price advance beyond what would have otherwise occurred, "... the poor record of this technique in predicting the rate of inflation prior to controls does not inspire confidence in their answer, and evidence from this source must be regarded as inconclusive." [1973 CEA Report, p. 61] relative price ceilings established by the system would become more potent sources of distortions. More and more companies would hit their profitmargin ceilings, with adverse consequences for cost control and for investment incentives. More insistence on formal and equitable procedures would arise, litigation would multiply, and administrative costs, public and private, would increase greatly. Less tolerances of the inevitable delays and red tape of the system would be forthcoming. ${ }^{24}$

Under Phase III, "voluntary" price-wage guidelines were kept, but the administrators of the guidelines, the Price Commission and Pay Board, were relieved from service. The CISC and the Committee on Interest and Dividends were retained.

Supervisory authority is maintained by the Cost of Living Council. Mandatory controls remain on food processing and distribution, and the construction and health industries. Recently, ceilings on meat prices were imposed.

In addition to the recent price control activity, a number of steps have been taken to increase the supply of certain goods. These actions include suspension for 1973 of wheat acreage allotments, disposal of some Government-owned stocks of grains, and suspension for 1973 of all import controls on meat in order to get food prices down. Import controls on oil are also being relaxed. Similar actions to remove artificial restrictions on the supply of other goods and services would likely result in a slowing of price advances in many areas.

Two recent studies on one of these artificial supply restrictions - import controls - suggest that such controls are costing American consumers billions of dollars a year. Stephen Magee found that the total costs to the United States of existing tariff and quota bar riers - both here and abroad - run between $\$ 7.5$ and $\$ 10.5$ billion annually. 30 Andrew F. Brimmer concluded that sugar quotas may cost American consumers as much as $\$ 300$ to $\$ 500$ million per year, manmade fiber and woolen textiles quotas $\$ 300$ million, and petroleum quotas $\$ 5$ billion. ${ }^{21}$ In general, Mr. Brimmer found that ". . in categories in which foreign competition was restricted because of quota limitations, prices rose more rapidly than in categories where imports were free to expand." 32

\footnotetext{
291973 CEA Report, pp. 69-70.

30Stephen P. Magee, "The Welfare Effects of Restrictions on U.S. Trade," Brookings Papers on Economic Activity (3: 1972).

31 Andrew F. Brinmer, "Imports and Economic Welfare in the United States" (a speech to the Foreign Policy Association, February 16, 1972, p. 5).

;2Ibid., p. 26.
} 
Given time, the repeal of legislation designed to benefit certain groups through insuring their monopoly powers would likely result in substantial gains in the effort to slow price advances. Some efforts made in this direction prior to August 1971 were overridden by the desire to show more immediate progress in curbing inflation. The public at large indicated a desire for faster progress in 1971 and a strict controls program was eventually adopted. General displeasure with a possible pick-up in the inflation rate in 1973 could be interpreted by some to indicate a "need" to return to such programs. Indeed, this seems already to have happened in the case of meat price ceilings.

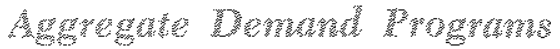

Aggregate demand programs are reflected in an administration's overall budget. The unified budget messages prepared by the current Administration during the past few years have consistently been overly optimistic in terms of holding down the magnitude of the deficits. ${ }^{33}$ There is nothing unusual about this, but some of the errors have been quite large, so that more stimulus may have been imparted to the economy than originally intended. For example, the first estimate for the fiscal year 1971 unified budget was a $\$ 1.3$ billion surplus; the realized budget showed a $\$ 23$ billion deficit. Adoption of the high-employment budget principle for fiscal years 1972 and 1973 provided no guarantee of realized budget targets. ${ }^{34}$

The large deficits of recent years have created diffculties for monetary authorities. Because of the intervention in the Government securities market to resist rising interest rates, monetary aggregates, such as the money stock, have probably increased at rates more rapid than desired. In fact, monetary growth accelerated each year from 4.3 percent in 1969 to 7.4 percent in 1972 .

The large deficits and rapid monetary expansion in the recent past have helped bring the unemployment rate down from 6 percent to the 5 percent level more rapidly than otherwise would have occurred, but may also have laid the groundwork for demand-pull price pressures. Further strong monetary and fiscal stimulus could induce unemployment to continue to fall, but at

\footnotetext{
33artially because of the unexpected influence of tax overwithholding, the deficit for fiscal year 1973 projected in the 1972 budget message may be met.

34 For these two years, the sum of the error for the highemployment budget, as calculated by this Bank, is expected to be about $\$ 7$ billion on the deficit side. On a national income accounts basis, the Federal budget deficit has inereased each fiscal year from $\$ 1.3$ billion in 1970 to an estimated $\$ 26.6$ billion in 1973. See 1973 CEA Report, p. 271.
}

some point in the vicinity of the normal unemployment rate, price pressures begin to accelerate.

This, of course, is the problem of re-entry into the zone of full recovery - a zone in which smaller and smaller gains in employment are achieved only at the cost of accelerating inflation. Much of the theme of the latest budget message reflects concern for the proper re-entry into the full recovery stage.

During the past 2 years, with the economy operating below capacity and the threat of inflation reced. ing, the Federal budget provided fiscal stimulus that moved the economy toward full employment. The 1974 budget recognizes the Federal Government's continuing obligation to help create and maintain through sound monetary and fiscal policies - the conditions in which the national economy will prosper and new job opportunities will be developed. However, instead of operating primarily as a stimulus, the budget must now guard against inflation. ${ }^{35}$

Despite the obvious recognition of the re-entry problem, there are a number of factors working against the realization of another year or more of receding inflationary pressures. First, Government expenditures remain difficult to control. Many items in the budget, such as interest payments on the national debt, are outside the scope of year-to-year budget decisions. Also, it is the responsibility of Congress to actually make the necessary appropriations, a task usually approached in piece-meal fashion. The result often has been actual Federal expenditures in excess of those projected by any Administration's initial budget, despite periodic fund impounding.

Second, the acceleration of consumer prices to a 3.9 percent rate in the second half of 1972 from a 2.9 percent increase in the preceding year, in the face of Phase II controls, suggests the bottom of the slowing in price rises may already have been reached. The similar acceleration of wholesale prices in the second half of 1972 and into early 1973 provides additional evidence that re-entry into the full recovery zone, with the usual implications for inflation, is occurring..$^{36}$ The true underlying price situation is clouded because of adverse short-run agricultural supply factors, the absence of adequate information on the current normal rate of unemployment, and the influence of

35The Budget of the United States Government, Fiscal Year 197 A (Washington, D.C.: U.S. Government Printing Office, $1973)$, p. 4.

36 fncreases in the wholesale prices of agricultural commodities accounted for much of the wholesale price acceleration in the second half of 1972. Consumer food prices in early 1973 probably reflect movements of these wholesale prices. Moreover, the recent devaluation of the dollar will tend to in crease prices of imported itens, thereby resulting in a rise in the consumer price index, which includes a number of such items. 
controls on price indexes. Just as the moral suasion of recent months made the "prime" interest rate a poor indicator of true market pressure at times, so too have the various price indexes possibly been emitting misleading signals.

A third factor encouraging skepticism of the possibility that inflationary pressures will taper off in the near future is the rapid growth of the money stock and large Government deficits that occurred throughout much of 1972 . A deficit of $\$ 18.2$ billion in the second half of calendar year 1972 (national income accounts basis) and a 7.8 percent rate of increase of the money stock over that period have not yet fully worked through the economy. The rate of growth of the privately held money stock has slowed in early 1973 . However, the lags associated with earlier rapid monetary growth continue to influence current economic activity.

The Administration recognizes the view that stopand-go policies are not inevitable. In several instances, long-run considerations are reflected in budget and CEA documents. The 1972 CEA Report included a discussion of the long-run characteristics of the unemployment-inflation problem. An entire chapter of the 1972 Report focused on the long-run outlook of resource needs for the various sectors over a five-year period. The 1974 budget message presented, for the first time, a detailed report of the following year's budget picture.

All the recorded long-run emphasis, however, has not necessarily been reflected in policy actions over the past few years. A desire to reduce unemployment in the face of rapid labor force growth has probably been the principal factor underlying the ever-accelerating expansionary actions in the $1969-72$ period. Had it not been for adverse demographic and geographic influences on the structure of the labor force and employment during this time, aggregate demand policy actions might have been more in keeping with longrun price stability.

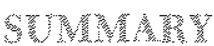

High rates of unemployment and price advances have persisted in the U.S. economy the past few years despite, or perhaps because of, the use of a wide variety of corrective actions. Given a basically stable economy, the use of a succession of stop-and-go policies to attain short-run goals is more the source of, than the solution to, many longer-run economic problems.

The experience of other recession and early-recovery periods indicates that the temporary simultaneous occurrence of considerable unemployment and inflationary pressures is not unusual. However, the current inflation rate, as the economy nears the full recovery stage, is well above that of earlier comparable periods.

Recent policy actions, as recorded in annual budget and economic report documents, reflect considerable innovation in the price control area. Structural employment policies have been marked primarily by consolidation of earlier programs. Economic spokesmen have repeatedly called for the lowering of artificial barriers to employment such as restrictions on entry by various businesses or unions, outdated licensing requirements, and minimum wage laws. As yet, no vigorous, concerted effort has been forthcoming. ${ }^{3 T}$

Sweeping price policies were adopted in the form of the Phase I, II and III control programs. Precisely how much these programs lowered the rate of increase of measured price indexes is unknown. Moreover, the true inflation rate may have been masked by controls. Expansionary monetary and fiscal actions in the 197072 period have speeded employment gains, but may also have set the stage for renewed inflationary pressures.

The budgeted ceiling on Federal expenditures, if attained, could be accompanied by more moderate fiscal and monetary stimulus. A slowing in the growth rates of some monetary aggregates has already occurred in the early months of 1973. If aggregate demand policies of moderation are either "too little or too late," calls for renewed, economy-wide price controls may well be heeded because of their apparent "success" in a period of slack demand. Experience in this country, as well as in other countries, indicates that vigorous controls cannot succeed under conditions of strong excess demand.

37 See Arthur F. Burns, The Problem of Inflation, an American Economic Association address, December 29, 1972. Mr. Burns lists a number of specific structural employment measures and concludes "There is no quick or easy path to meaningful structural reform. But I see no real alternative if our national aspiration for prosperity without inflation is to be realized, while free enterprise and individual choice are being preserved." (pp. 21-22)

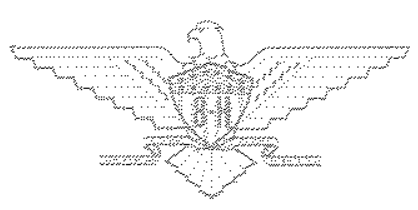

